\title{
Pemberdayaan Perempuan Pengrajin Genteng Di Desa Ngembalrejo Kabupaten Kudus: Upaya Di Tengah Marjinalisasi dan Eksploitasi
}

\author{
Siti Malaiha Dewi ${ }^{1}$, M. Amin ${ }^{2}$ \\ ${ }^{1}$ IAIN Kudus \\ ${ }^{2}$ Yayasan Nusantara Satu Kudus \\ dewimalaiha@yahoo.com ${ }^{1}, \underline{\text { amynmoh@gmail.com }}{ }^{2}$
}

\begin{abstract}
Ideally, women who spend time and energy in the workplace are directly proportional to the bigh quality of life. However, this is not the case with tile craftsmen in the circle of the Holy IAIN campus. Women tile craftsmen have no job certainty, guaranteed work safhety, and high health risks. There is no certainty about work because it is only employed during the dry season, while in the rainy season it is idle. However, this condition continues because there are no other job choices. Therefore, life skill training in the manufacture of pastries, wet cakes, and application trays as alternatif businesses is expected to answer the uncertainty of work so far. This activity was attended by 20 women tile craftsmen with direct practice methods, then training in family financial management. As a result, female tile craftsmen have alternatif skills so that no more women are unemployed when the rainy season arrives, so they can increase their income and confidence. In addition, a women's association of tile craftsmen was successfully established as a place to share and mutually reinforce women among tile craftsme.
\end{abstract}

Keywords: Female tile craftsman, Ngembalrejo Kudus, marginalization, exploitation

\section{Pendahuluan}

Fenomena perempuan bekerja dan berusaha bukanlah hal baru dalam kehidupan, apalagi setelah Women in Development (WID) menjadi salah satu pendekatan dalam pembangunan, maka banyak perempuan berduyun-duyun memasuki dunia industri baik industri besar maupun industri kecil yang disebut sebagai usaha mikro ${ }^{1}$. Usaha mikro digambarkan sebagai usaha-usaha marjinal dan subsisten yang diantaranya ditandai dengan: pertama, jenis transaksi jual beli dalam jumlah kecil; kedua, sebagian transaksi dilakukan dengan orang yang dikenal; dan ketiga kesepakatan yang dibangun bersifat langsung dan berdasarkan kepercayaan. Di Indonesia, usaha mikro merupakan mayoritas, sebab jumlahnya mencapai 98\% dari total unit usaha (BPS, 2017) dan $60 \%$ perempuan berada di dalamnya ${ }^{2}$. Namun masuknya perempuan ke dalam kerja-kerja produktif seperti usaha mikro tidak dapat dipandang sebagai bagian dari capaian pembangunan sebab usaha mikro menjadi pilihan orang-orang (perempuan) yang tidak mendapatkan manfaat dari tumbuhnya industri-industri besar dan mereka yang terlempar dari sektor formal karena

1 Dewayanti, Ratih. dkk. Marjinalisasi dan Eksploitas Perempuan Usaha Mikro di Perdesaan Jawa, Bandung: AKATIGA. 2004: 23

2 Ibid. 3

Volume 2, Number 2, November 2018| 233

Pemberdayaan Perempuan Pengrajin Genteng Di Desa Ngembalrejo Kabupaten Kudus 
hubungan industrial yang mengabaikan siklus perempuan seperti perkawinan dan melahirkan ${ }^{3}$.

Demikian halnya yang terjadi di Kabupaten Kudus. Sebagai kota yang dijuluki sebagai 'kota industri', munculnya industri-industri besar seperti Pabrik Rokok Djarum, Pabrik Rokok Nojorono, Polytron, dan PT Pura Barutama pun diikuti dengan munculnya industri-industri kecil dan usaha mikro sebagai peluang yang tersisa bagi mereka (perempuan) yang tidak terserap pada industri-industri besar tersebut. Contohnya: usaha bordir, konveksi, pembuatan jenang, makanan ringan, mayoritas pekerjanya adalah perempuan. Bahkan usaha yang terkesan maskulin seperti pembuatan genteng pun didominasi perempuan. Sentra industri pembuatan genteng terletak di bagian Timur Kota Kudus tepatnya di Desa Ngembalrejo, Kecamatan Bae, Kabupaten Kudus. Di desa ini juga kampus IAIN Kudus berada. Terdapat 83 usaha pembuatan genteng yang tersebar mengelilingi kampus dengan tenaga kerja berjumlah kurang lebih 500 orang yang sebagian besarnya adalah perempuan atau dalam tulisan ini disebut sebagai 'perempuan pengrajin genteng'.

Tidak hanya jumlahnya yang dominan tetapi pembagian kerja dalam mata rantai produksi pembuatan genteng pun perempuan lebih banyak. Lebih jelas lihat tabel di bawah ini:

\section{Tabel 1}

Tahapan Produksi Genteng dan Pembagian Kerja

\begin{tabular}{|c|c|c|c|c|}
\hline $\begin{array}{l}\text { Tahapan } \\
\text { pekerjaan }\end{array}$ & Pelaku & Lokasi & Waktu & Sistem pembayaran \\
\hline $\begin{array}{l}\text { Penggilingan } \\
\text { lempung }\end{array}$ & $\begin{array}{l}\text { Laki-laki } \\
\text { (6 orang) }\end{array}$ & Tempat usaha & 3 jam & $\begin{array}{l}\text { Langsung } \\
\text { Rp. } 180.000 \text {,- per rit }\end{array}$ \\
\hline Nyetak. & Perempuan & Tempat usaha & $\begin{array}{c}\text { Pagi }(07.30-11.00) \\
\text { dan } \\
\text { siang }(14.00-16.00)\end{array}$ & $\begin{array}{l}\text { Langsung } \& \text { terkadang } \\
\text { ditunda setelah genteng laku } \\
\text { Per genteng Rp. } 200 . \text { Sehari } \\
\text { rata-rata } 150 \text { genteng. Jadi } \\
\text { Rp. } 30.000,-\end{array}$ \\
\hline Menjemur & Perempuan & Tempat usaha & $\begin{array}{c}\text { Pagi (08.00-10.00) } \\
\text { dan } \\
\text { sore }(15.00-17.00)\end{array}$ & $\begin{array}{l}\text { Ditunda setelah genteng laku } \\
\text { Rp } 100 \text { per genteng x } 300= \\
\text { rp. } 30.000\end{array}$ \\
\hline Nyisik/ ngerik & Perempuan & Tempat usaha & $\begin{array}{c}\text { Pagi (08.00-11.00) } \\
\text { dan } \\
\text { siang (14.00-16.00) }\end{array}$ & $\begin{array}{l}\text { Ditunda setelah genteng laku } \\
\text { Rp } 100 \text { per genteng x } 300= \\
\text { Rp. } 30.000\end{array}$ \\
\hline Momot & $\begin{array}{l}\text { Laki-laki dan } \\
\text { perempuan } \\
\text { (8-10 orang) }\end{array}$ & Tempat usaha & Pagi 08.00-14.00 & $\begin{array}{l}\text { Langsung } \\
\text { Rp 50.000/ orang }\end{array}$ \\
\hline Mbakar & $\begin{array}{l}\text { Laki-laki (2 } \\
\text { orang) }\end{array}$ & Tempat usaha & 12 jam & Rp. 150.000 \\
\hline
\end{tabular}

Sumber data: Hasil Forum Group Discussion (FGD) dengan pemilik dan perempuan pengrajin genteng, 26 September 2016

Tabel di atas menunjukkan bahwa perempuan dominan dalam tahapan-tahapan produksi dan lebih panjang waktu bekerjanya dibandingkan laki-laki, namun penghargaan terhadap kerja

\footnotetext{
${ }^{3}$ White (1991: 20
} 


\section{ENGAGEMENT}

JurnalPengabdianKepadaMasyarakat

ISSN : 2579-8375 (Print)

ISSN : 2579-8391(Online)
This work is licensed under a Creative Commons

Attribution-ShareAlike 4.0 International License.

perempuan lebih rendah. Umumnya, setiap hari mereka membawa pulang uang Rp. 30.000,dengan mencetak sekitar 150 genteng dengan jam kerja mulai jam 07.30 WIB (setelah menyelesaikan urusan domestik) dan istirahat pulang sekitar jam 11.00 WIB (untuk menyiapkan makan siang keluarga). Biasanya mereka kembali lagi untuk mencetak sampai jam 15.00 WIB. Namun, jika ada kepentingan keluarga mereka akan meninggalkan pekerjaan. Waktu kerja yang sangat fleksibel disebut part-time employment yaitu jenis kerjaan yang memberikan sejumlah fleksibilitas waktu kepada pekerjanya ${ }^{4}$. Sistem ini membantu perempuan mengkombinasikan perannya sebagai pengelola rumah tangga dan sebagai pekerja.

Di samping mencetak, mereka juga menjemur dan mengikir yaitu meratakan pinggiran genteng yang sudah kering agar kelihatan bagus sebelum dibakar. Biasanya mereka nyambi tiga tahapan tersebut. Namun, kerja yang begitu menyita waktu dan kemampuan fisik tersebut, uang yang mereka bawa pulang per harinya habis hanya untuk konsumsi keluarga sehari-hari. Parahnya lagi, terkadang upah dibayarkan setelah genteng laku. Maka tidak heran, meski perempuan disana banyak menghabiskan waktunya untuk bekerja, namun kualitas hidup mereka tidak meningkat sebab minimnya manfaat yang diterimanya sebagaimana terungkap dalam wawancara berikut:

"Kulo niki sampun kerjo ket alit mbak, kulo piyambak lulus SD langsung nderek kerjo bapak ibu, berarti kulo sampun kerjo sekitar 20 tahun. Ngantos niki nggih mboten gadah nopo-nopo. Duite telas kagem maem. Lha dus pundi malih, daripada mboten bayaran, wong kulo mboten gadah ijasah duwur. Menawi gadah kulo saged mlebet pabrik".

(saya sudah bekerja mulai kecil, lulus SD langsung ikut kerja Bapak Ibu membuat genteng. Berarti saya sudah bekerja 20 tahun-an. Tapi sampai sekarang tidak punya apaapa. Upahnya Hanya cukup untuk makan saja. Bagaimana lagi, daripada tidak gajian. Memang saya tidak punya ijasah tinggi kalau punya saya bisa masuk pabrik).

Minimnya upah yang diterima perempuan pengrajin genteng diakibatkan adanya anggapan bahwa pekerjaan-pekerjaan yang dilakukan perempuan seperti nyetak, ngerik, dan menjemur adalah pekerjaan yang tidak mengandung risiko. Padahal, risiko kerusakan juga sering dihadapi pengrajin perempuan.

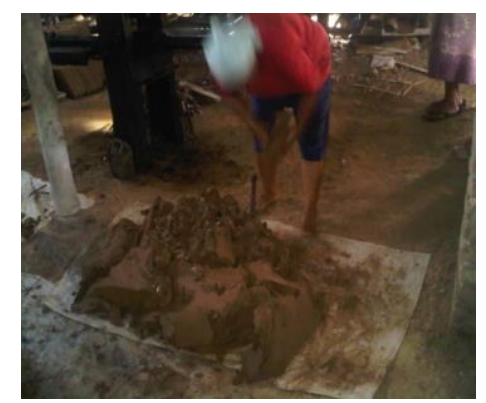

Gambar 1

Nguleni lempung

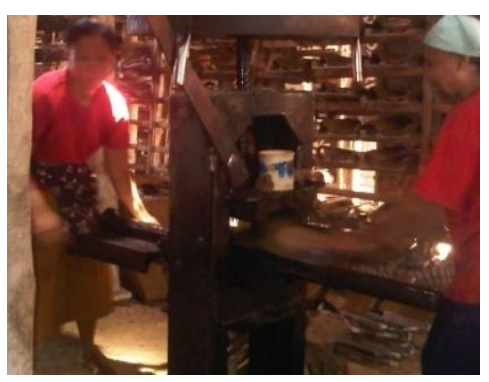

Gambar 2

Mencetak

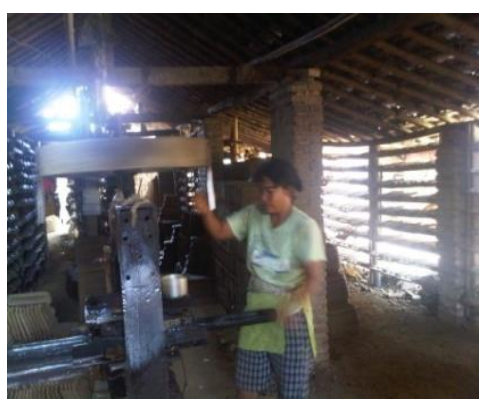

Gambar 3

Mencetak

${ }^{4}$ Ibid. 113

Volume 2, Number 2, November 2018| 235 Pemberdayaan Perempuan Pengrajin Genteng Di Desa Ngembalrejo Kabupaten Kudus 




Gambar 4

Melepas cetakan

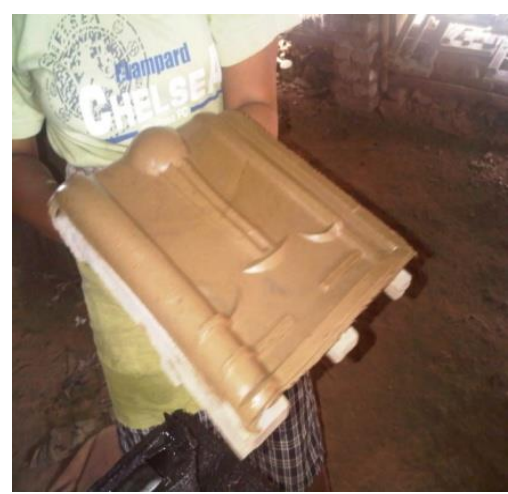

Gambar 5

Hasil cetakan

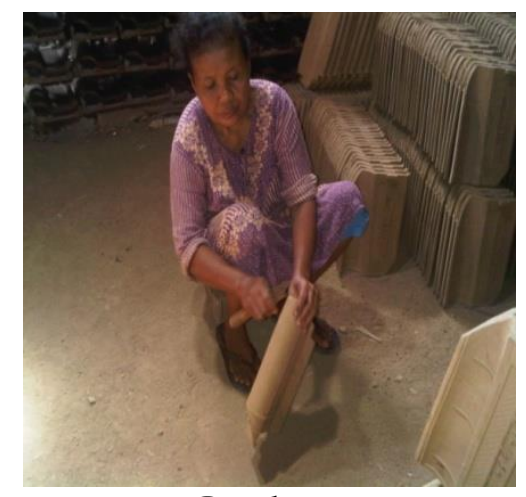

Gambar 6

Ngerik

Selain risiko kerusakan pada produksi, risiko kesehatan yang tinggi juga dialami oleh perempuan pengrajin genteng, sebagaimana hasil wawancara berikut ini:

“........Nek pegel-pegel sampun biasa mbak, wong sampun dados pendamelane kulo kok. Albamdulillah nek, watuk-watuk. kulo namung tumbas obat-obat teng toko-toko. Menawi sesak nafas nembe wonten dokter. Gatel-gatel teng astane kulo sebab ngoleske oli niki njïh mpun biasa. Mboten kulo raoske..."

(“.....kalau pegal-pegal itu sudah biasa, sebab sudah menjadi pekerjaan sehari-hari. Alhamdulilah kalau batuk cukup dengan obat di warung sebelah. Kalau sesak nafas baru ke dokter. Gatal-gatal di tangan akibat tidpa hari mengoleskan oli di genteng itu biasa, tidak saya rasakan...”).

Hasil wawancara di atas menunjukkan bahwa pekerjaan yang mereka jalani tidak aman (insecure) dan penuh dengan risiko kesehatan seperti batuk-batuk, sakit pernafasan, sakit kulit akibat tiap hari harus mengoles genteng dengan oli, maupun maupun yang terkait dengan fungsifungsi reproduksi mereka. Namun, mereka tetap mempertahankanya meski penghasilan yang diperoleh tidak sebanding dengan beban pekerjaan dan risiko kerja yang diterima, sebab lapangan kerja itulah yang tersisa bagi pemenuhan kebutuhan mereka. 'Daripada tidak mempunyai penghasilan', demikian jawaban mereka. Sementara tidak ada jaminan keselamatan kerja sedikit pun dari juraganya. Jika terjadi kecelakaan kerja misalnya, maka mereka yang menanggungnya. Kalau tidak memiliki uang, mereka akan berhutang kepada juragan dan juragan menganggap sebagai uang muka untuk mengikat mereka bekerja. 


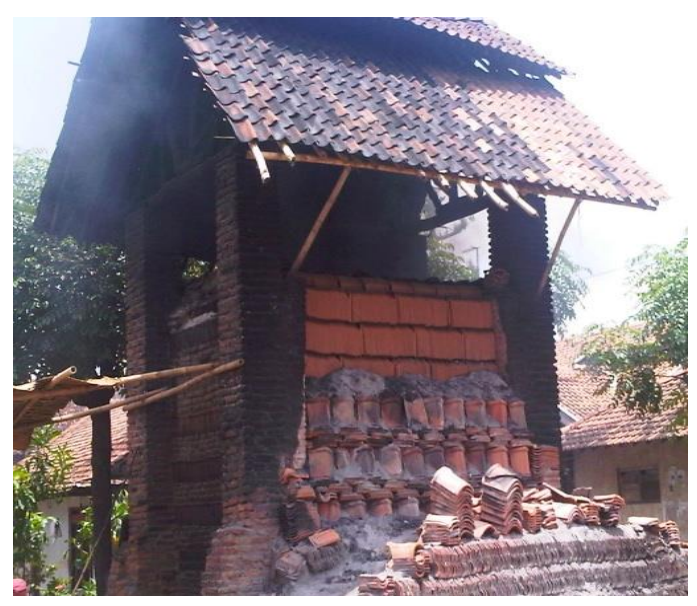

Gambar 7

Tempat pembakaran genteng

Selain tidak adanya jaminan kesehatan dan keselamatan kerja, jaminan kelangsungan atas pekerjaan bagi perempuan pengrajin genteng pun tidak ada. Ketidakpastian atas pekerjaan disebabkan beberapa faktor, diantaranya: 1) Usaha pembuatan genteng adalah usaha yang sangat rentan akan keberlanjutanya, mengingat sumber bahan bakunya sangat tergantung dari sumber alam yang tidak dapat diperbaharui yaitu tanah liat atau disebut dengan lempung; 2) Ketergantungan terhadap musim. Usaha pembuatan genteng hanya bisa diproduksi di saat musim kemarau, sementara di musim penghujan otomatis proses produksi terhenti dan otomatis perempuan pengrajin genteng pun menganggur; 3) Ketidakpastian kerja juga disebabkan tidak adanya sistem pekerja tetap alias 'buruh lepas'. Mereka dipekerjakan ataupun tidak atas dasar kemauan juragan. Tidak ada bargaining position dan tidak ada pilihan bagi mereka kecuali menunggu panggilan juragan mana yang akan mempekerjakan. Selain tidak adanya bargaining position perempuan pengrajin genteng terhadap juragan, relasi yang tidak seimbang juga muncul karena ada anggapan dari perempuan pembuat genteng bahwa hanya usaha pembuatan genteng saja yang tersisa bagi mereka dan tidak ada pilihan lain di luar itu karena mereka merasa tidak memiliki ijazah dan ketrampilan selain membuat genteng. Maka satu-satunya jalan bagi mereka adalah menerima kondisi yang ada.

Apabila dipetakan maka persoalan-persoalan di atas dapat digambarkan seperti bagan pohon masalah di bawah ini: 




Sumber: Hasil FGD Perempuan Pengrajin Genteng, 26 September 2016

Adanya berbagai masalah di atas, maka berdasar hasil FGD yang diinisiasi oleh Tim Pendamping muncul keinginan-keinginan perempuan pengrajin genteng untuk berubah. Harapan yang dimaksud adalah adanya relasi yang adil dan seimbang antara perempuan pengrajin genteng dengan juragan pemilik usaha pembuatan genteng, ditandai dengan adanya: 1)Bargaining position yang kuat dari perempuan pengrajin genteng terhadap juragan sehingga mereka mempunyai keberanian untuk bernegosiasi dalam hal pengupahan, jaminan kesehatan, dan kepastian kerja; 2) Munculnya kesadaran pada diri perempuan pembuat genteng bahwa masih ada pilihan-pilihan bagi mereka untuk bekerja selain menjadi buruh pembuat genteng; 3) Terwujudnya komunikasi yang bersifat dialogis antara perempuan pengrajin genteng dengan juragan pemilik usaha 


\section{ENGAGEMENT}

QurnalPengabdianKepadaMasyarakat

ISSN : 2579-8375 (Print)

ISSN : 2579-8391(Online)
This work is licensed under a Creative Commons

Attribution-ShareAlike 4.0 International License.

pembuatan genteng.

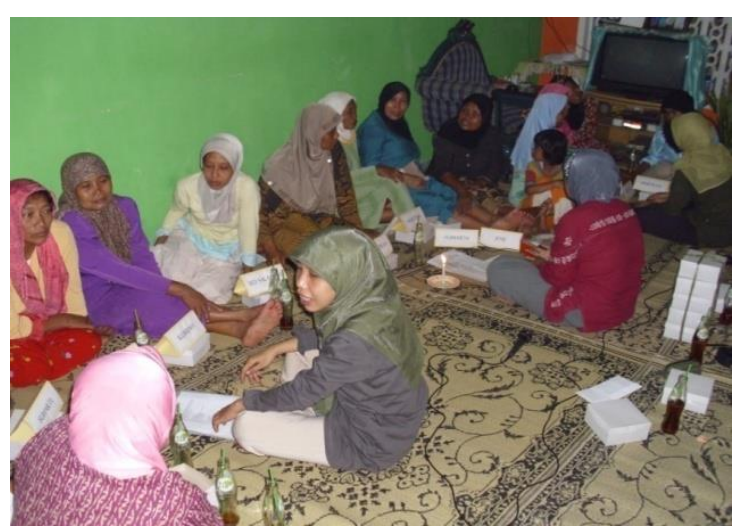

Gambar 8. Suasana FGD



Gambar 9. Suasana FGD

Jika relasi yang seimbang terwujud maka kualitas hidup perempuan pengrajin genteng akan mengalami perubahan ke arah yang lebih baik ditandai dengan layaknya upah yang diterima perempuan pengrajin genteng, adanya kepastian kerja, dan terjaminannya kesehatan dan keselamatan kerja. Jika kualitas hidup perempuan meningkat, maka kualitas hidup anak pun akan meningkat pula, diantaranya tentang pendidikan mereka karena tercukupinya dana pendidikan. Jika digambarkan, maka kondisi yang diharapkan terwujud dapat dilihat pada bagan di bawah ini:

Bagan 2

Hirarchi Analisa Tujuan

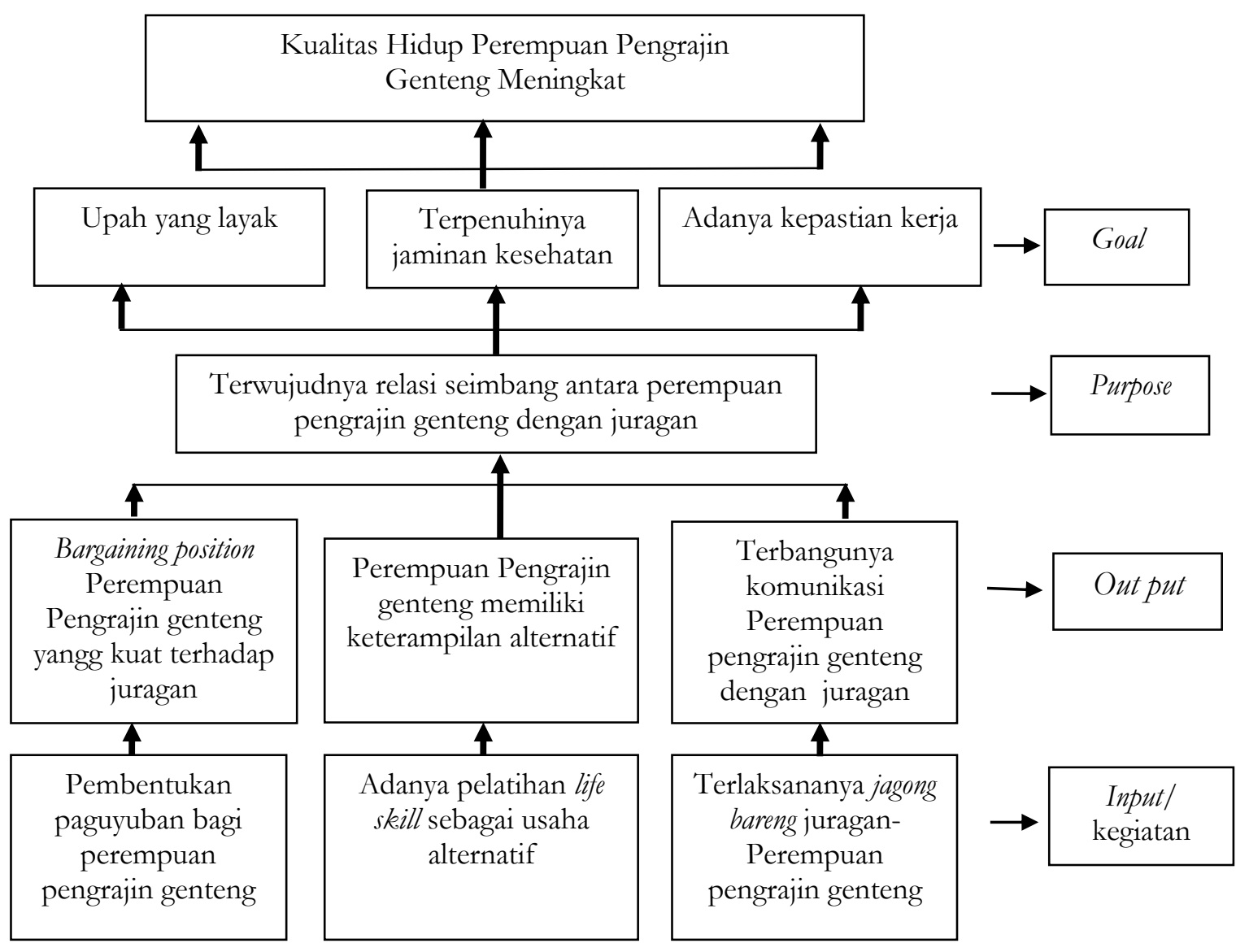

Volume 2, Number 2, November 2018| 239 
Berdasarkan permasalahan-permasalahan di atas serta fakta bahwa keberadaan sentra usaha pembuatan genteng sangat dekat melingkari kampus STAIN Kudus (Saat ini sudah menjadi IAIN Kudus), maka sangat berdosa kalau kami berdiam diri dan tidak tergerak untuk melakukan upaya - upaya pendampingan dan sangat ironi, jika di kampus yang selalu mengajarkan bagaimana mencipta keadilan, menghilangkan kedholiman dan kesenjangan, tetapi di lingkar kampus, tidak terperhatikan. Sangat ironi juga jika dikampus yang setiap hari berlangsung proses pendidikan, sementara di sebelahnya tidak ada satupun anak yang mengenyam pendidikan tinggi dikarenakan tidak ada biaya karena upah yang diterimanya hanya cukup untuk konsumsi keluarga sehari-hari, maka perempuan pengrajin genteng di Desa Ngembalrejo kecamatan Bae Kabupaten Kudus menjadi fokus dampingan dalam pengabdian ini.

\section{Metode}

Prinsip utama dalam menjalankan proses pengabdian ini tim pendamping berpegang pada sebuah pernyataan kunci dari Mao Tse Tung sebagai berikut:

"Perhatikan sungguh-sungguh gagasan yang datang dari rakyat, yang masih terpenggal dan belum sistematis. Pelajari gagasan tersebut bersama mereka, sehingga menjadi gagasan yang lebih sistematis. Menyatulah dengan rakyat. Kaji dan jelaskan kembali gagasan yang datang dari mereka itu, sehingga mereka benar-benar paham bahwa gagasan itu milik mereka. Terjemabkan gagasan tersebut menjadi aksi, dan uji kebenaran gagasan tadi melalui aksi. Begitu seterusnya diulang-ulang secara ajeg, agar gagasan tersebut menjadi lebib benar, lebih penting dan lebib bernilai sepanjang masa” Demikian itulah membangun ILMU PENGETAHUAN RAKYAT"5.

Prinsip di atas kemudian tim pendamping terjemahkan dalam langkah operasional di lapangan dengan metode penggalian dan analisis data yang relevan. Karena itu dalam kerangka kerja ini tim peneliti menggunakan beberapa strategi. Adapun strategi yang dimaksud meliputi: Pertama, Identifikasi Masalah/Assessment. Langkah awal yang tim Pendamping lakukan adalah melakukan pemetaan problem dengan perempuan pengrajin genteng dengan cara berkunjung ke rumah-rumah mereka, sehingga diketahui aktifitas sehari-hari dan berbagai persoalan yang dihadapi. Dalam hal ini Tim pendamping menggunakan salah satu alat analisis gender yaitu metode Harvard sehingga dapat tergambar pola pembagian kerja anggota keluarga perempuan pengrajin genteng. Selain itu, dilihat juga akses, partisipasi, kontrol, dan manfaat yang diterima perempuan pengrajin perempuan dalam keluarganya. Hasil pembacaan Tim Pendamping tersebut kemudian dijadikan guide atau bahan diskusi bersama atau FGD dengan komunitas dampingan untuk menemukan core problem dan main problem (lihat bagan 1). Selain

${ }^{5}$ Abdullah Faishal; 2008

Volume 2, Number 2, November 2018| 240

Pemberdayaan Perempuan Pengrajin Genteng Di Desa Ngembalrejo Kabupaten Kudus

Siti Malaiha Dewi, M. Amin 
memetakan masalah, pada tahap ini juga dilakukan: 1) Analisis sosial, ekonomi, budaya, dan lainnya, untuk mengetahui kebutuhan, potensi, peluang serta permasalahan yang ada, serta dilakukan analisis pihak terkait (Stakeholders analysis); dan 2) Analisis keunggulan yaitu mengenali keunggulan yang dimiliki oleh komunitas. Pada langkah ini peneliti mulai menemukan faktor apa yang bisa dikembangkan dengan melihat peluang-peluang yang ada pada komunitas tersebut.

Kedua, Perencanaan Program. Setelah dilakukan identifikasi kebutuhan, permasalahan yang dihadapi serta kekuatan dan peluang yang dimiliki, maka langkah selanjutnya adalah mendesain program secara bersama-sama dengan komunitas dampingan. Berdasarkan hasil analisis kebutuhan, disusunlah dalam bentuk draft logical framework untuk bahan awal yang akan dibahas kembali dalam tim yang melibatkan berbagai pihak terkait untuk merumuskan dan memutuskan sasaran (goal), tujuan antara (purpose), keluaran (out put) serta bentuk kegiatan.

Tabel 2

Ringkasan Narative Program

\begin{tabular}{|c|c|c|c|}
\hline Goal & \multicolumn{3}{|c|}{$\begin{array}{l}\text { Kualitas hidup perempuan pengrajin meningkat (upah meningkat, adanya jaminan } \\
\text { kesehatan, dan kepastian kerja) }\end{array}$} \\
\hline Purpose & \multicolumn{3}{|c|}{ Terwujudnya relasi yang seimbang antara perempuan pengrajin genteng engan juragan } \\
\hline $\begin{array}{l}\text { Hasil } \\
\text { (output) }\end{array}$ & $\begin{array}{l}\text { Bargaining position Perempuan } \\
\text { Pengrajin genteng yang kuat } \\
\text { terhadap juragan }\end{array}$ & $\begin{array}{l}\text { Terbukanya wawasan } \\
\text { bahwa ada pilihan lain } \\
\text { selain membuat genteng }\end{array}$ & $\begin{array}{lr}\text { Adanya } & \text { komunikasi } \\
\text { antara } & \text { perempuan } \\
\text { pengrajin } & \text { genteng } \\
\text { dengan juragan } & \end{array}$ \\
\hline $\begin{array}{l}\text { Kegiatan } \\
\text { (Input) }\end{array}$ & $\begin{array}{l}\text { 1. Menginisiasi terbentuknya } \\
\text { Paguyuban perempuan } \\
\text { pengrajin genteng }\end{array}$ & $\begin{array}{l}\text { 2. Pelatihan life skill } \\
\text { sebagai usaha } \\
\text { alternatif }\end{array}$ & $\begin{array}{l}\text { 3. Terlaksananya jagong } \\
\text { bareng juragan- } \\
\text { perempuan } \\
\text { pengrajin genteng }\end{array}$ \\
\hline
\end{tabular}

Adapun program dan bentuk kegiatan yang direncanakan berdasarkan identifikasi kebutuhan perempuan pembuat genteng, meliputi:

1. Membentuk 'Paguyuban perempuan pengrajin genteng' yang berfungsi sebagai wadah bagi ibu-ibu pengrajin genteng untuk berbagi informasi seputar pekerjaan mereka dan sebagai wadah saling menguatkan.

2. Memfasilitasi terbukanya wawasan perempuan pengrajin genteng tentang usaha alternatif melalui pelatihan life skill

3. Memfasilitasi terwujudnya komunikasi yang dialogis antara juragan dengan perempuan pengrajin genteng melalui jagong bareng diantara keduanya.

Pihak-pihak terkait yang terlibat intensif dalam proses dampingan ini antara lain adalah :

(1) Perempuan Pengrajin Genteng di Dukuh Ngetuk, Desa Ngembalrejo Kabupaten Kudus yang menjadi kelompok dampingan. Diharapkan komunitas ini terlibat aktif dan intensif, baik pada tataran perencanaan, aksi, sampai refleksi dan evaluasi, dalam setiap program kegiatan 
dampingan; (2) Pemerintah Desa Ngembalrejo; (3) PKK Desa Ngembalrejo yang memberikan pelatihan alternatif; (4) Yayasan Nusantara Satu Kudus, sebuah lembaga yang bergerak pada penguatan ekonomi dan pendidikan masyarakat; (4) PSG STAIN Kudus; (5) Pemerintah Kabupaten (Pemkab) Kudus, dalam hal ini Dinas Koperasi dan perindustrian sebagai lembaga pemerintah yang akan berkontribusi dalam hal pendampingan pelatihan usaha alternatif dan Dinas Kesehatan yang melakukan pendampingan dalam hal kesehatan perempuan pengrajin genteng.

\section{Hasil dan Diskusi}

\section{Tahap Perencanaan}

Sebelum pelaksanaan kegiatan pemberdayaan dimulai, maka tim pelaksana melakukan rapat koordinasi dengan perempuan pengrajin genteng. Dilaksanakan di rumah Ibu Evi pada tanggal 5 Oktober 2016, hadir 12 orang perempuan pengrajin genteng sedangkan dari PSG STAIN Kudus dua orang. Acara dimulai jam dua siang sampai jam empat sore hari karena saat itu musim penghujan jadi tidak ada halangan bagi mereka untuk hadir karena sedang tidak bekerja. Rapat koordinasi menghasilkan beberapa kesepakatan antara lain, kegiatan yang pertama kali dilakukan di antara tiga kegiatan yang sebelumnya sudah terumuskan adalah pelatihan life skill. Setelah itu baru dilaksanakan kegiatan berikutnya yaitu Paguyuban perempuan pengrajin genteng' dan terakhir kegiatan jagong bareng antara juragan- perempuan pengrajin genteng. Alas an yang dikemukakan kenapa pelatihan life skill didahulukan sebab jika mereka memiliki ketrampilan dan pekerjaan alternatif maka akan merasa percaya diri di hadapan juragan untuk negosiasi tentang pengupahan dan lain-lain sebab jika sampai tidak dipekerjakan lagi mereka sudah memiliki alternatif kerjaan.

Setelah disepakati kegiatan pertama adalah pelatihan life skill. Ada usulan-usulan pelatihan diantaranya pelatihan pemanfaatan kain perca, pembuatan kue kering, pembuatan kue basah, dan pelatihan baki lamaran. Namun, dari beberapa alternatif tersebut, mereka memilih kegiatan pembuatan kue-kue kering dan basah serta kreasi membuat baki lamaran. Ketika ditawarkan kegiatan keterampilan pemanfaatan kain perca, beberapa peserta kurang antusias dengan alasan bahwa pembuatan keterampilan seperti itu kurang bermanfaat, disamping itu kebanyakan ibu-ibu anggota kelompok sudah tua dan merasa tidak telaten dengan membuat model keterampilan tersebut di atas. Hal ini juga dikuatkan oleh pernyataan ketua kelompok sebagai berikut: "Waah kalau membuat keterampilan yang njlimet, mayoritas ibu-ibu dikampung sini kurang telaten, mending membuat genteng". 
Selanjutnya dalam rapat koordinasi ini juga disepakati pelaksanaan kegiatan pelatihan, yang meliputi tempat dan waktu pelaksanaan. Waktu pelaksanaan pelatihan awal disepakati setiap hari jumat, jam 13.00 WIB, bertempat di rumah Bu evi. Di akhir rapat juga ada permintaan dari ibu-ibu pengrajin genteng untuk diajari bagaimana mengelola keuangan keluarga sehingga mereka bisa mengelola keuangan keluarga yang mereka peroleh nantinya.

\section{Tahap Pelaksanaan Kegiatan}

\section{a. Pelatihan Life Skill I- Pembuatan Kue Kering-Basah}

Pelatihan life skill terdiri dari dua kegiatan yang pertama pelatihan pembuatan kue basah dan kering. Pembuatan kue basah dengan lima resep, yang pertama adalah pembuatan kue bolu bownis, kue bolu ban (Tulban Cake), kue mangkok, kue bolu kukus jawa dan bolu kukus coklat. Adapun pelaksanaan kegiatan pelatihan pembuatan kue pada hari Jumat tanggal 7, 14, 21, dan 28 Oktober 2016. Pelatihan yang pertama adalah membuat kue brownis. Pelatihan ini disampaikan oleh perwakilan Yayasan Nusantara Satu Kudus. Dalam kegiatan ini jumlah peserta yang mengikuti 20 orang. Dalam pelatihan ini, karena peserta belum memiliki peralatan, maka peralatan sementara dipinjami oleh Yayasan Nusantara Satu Kudus yang kebetulan memiliki SMK Jurusan Tata Boga.

Acara dibuka oleh Bapak H. Abdul Fatih, SE selaku kepala desa Ngembal. Dalam sambutanya beliau merasa senang sekali dengan hadirnya teman-teman tim di tengah-tengah masyarakat dengan memberikan berbagai macam pelatihan yang nantinya akan bermanfaat pada ibu-ibu pengrajin genteng, khususnya ketika musim penghujan,di mana para ibu-ibu pengrajin genteng tidak bisa bekerja dikarenakan tidak ada cahaya matahari untuk menjemur genteng. Setelah itu Ibu Siti Malaiha Dewi, M.Si selaku ketua Tim Pendamping memandu acara pelatihan. Ibu-ibu peserta pelatihan terlihat sangat antusias dan merasa senang sekali, karena sebagian besar dari mereka belum pernah membuat brownis, apalagi resep yang diberikan narasumber sangat menarik. Pelatihan dimulai dengan penyampaian materi dan resep, setelah itu dipraktekkan secara langsung. Dimulai dengan memasukkan bahan adonan ke dalam mixer, kemudian setelah tercampur semuanya, dimasukkan ke dalam loyang dan siap di kukus selama 30 menit. Setelah 30 menit brownies kukus diangkat dan di potong-potong menjadi 30 dan di bagi-bagikan kepada peserta pelatihan. 

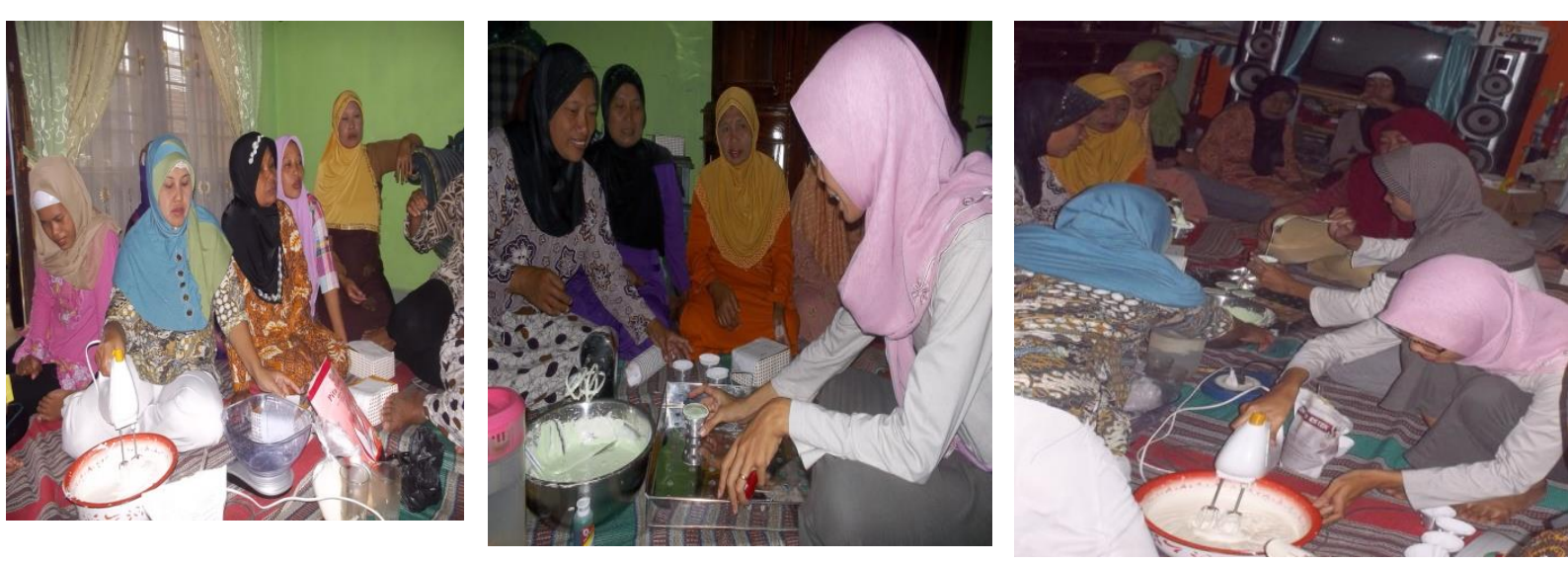

Gambar 10-12

Suasana pelatihan pembuatan kue basah
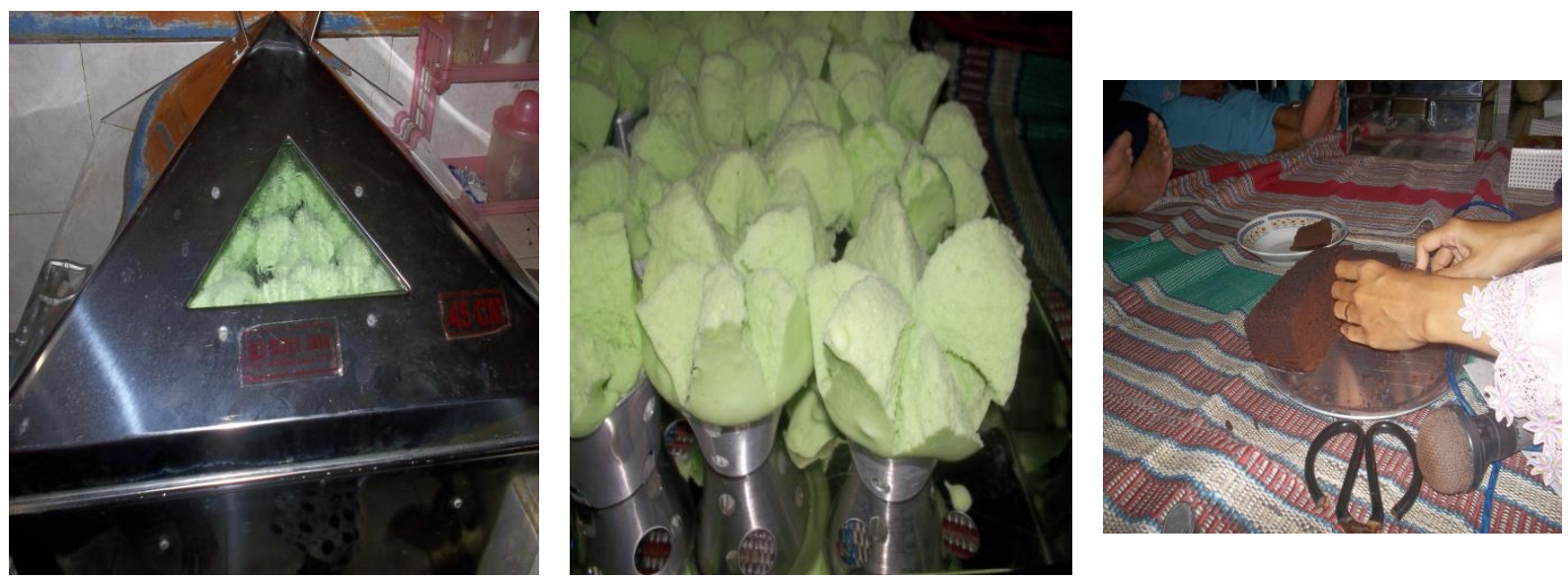

Gambar 13-15

Hasil pelatihan-brownies, bolu kukus
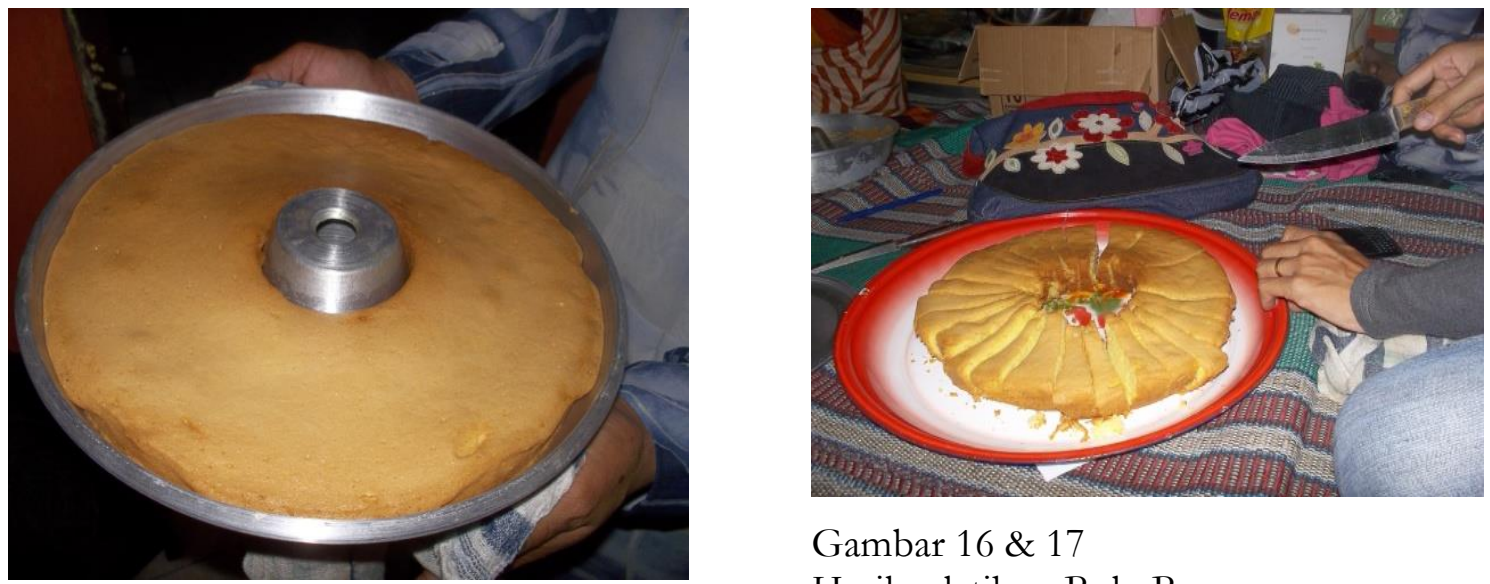

Gambar 16 \& 17

Hasil pelatihan-Bolu Ban

Pelatihan di minggu berikutnya adalah pelatihan bolu kukus pandan, pembuatan tulban cake (bolu ban), pembuatan bolu kukus coklat, bolu kukus jawa, terakhir pelatihan membuat stick 
pangsit. Tampaknya peserta sangat antusias dalam pembuatan kue-kue tersebut. Semua turut terlibat dalam proses pembuatan, ada yang mengaduk adonan dan ada pula yang memasak.

\section{b. Pelatihan Life Skill II - Baki Lamaran}

Pelatihan life skill II dilaksanakan sebanyak 2 kali. Pertama dilaksanakan pada hari Jum'at tanggal 4 Nopember 2016, yang dimulai pada pukul 16.00 - 18.00 WIB bertempat di rumah Bapak Yatno Dukuh Ngetuk Desa Ngembalrejo Kecamatan Bae Kabupaten Kudus. Peserta acara tersebut adalah 20 Orang perempuan pengrajin Genteng, dengan narasumber dari PKK. Pertama dipraktekkan kreasi membuat bebek kecil dari handuk dan membuat bunga dari kain batik yang panjangnya dua meter.

Acara menghias baki lamaran yang pertama ini lumayan lama, karena para ibu-ibu baru pertama kali melihat dan mempraktekkan langsung menghias beberapa bahan yang digunakan untuk bawaan ketika akan melamar. Ibu-ibu pun diberikan waktu untuk mempraktekkan secara langsung bagaimana membuat bunga yang cantik dari kain batik. Terlihat dari semangat ibu-ibu yang ingin sekali mencoba menghias kain, handuk dan lainnya menjadi tampilan yang lebih menarik. Hal ini, menunjukkan bahwa sebenarnya ibu-ibu ingin mempunyai ketrampilan lain yang mampu membantu perekonomian mereka selain bekerja sebagai pengrain genteng.

Pelatihan baki lamaran berikutnya dilaksanakan pada hari Jumat, 11 Nopember 2016, yang dimulai pada pukul 16.00-18.00 WIB bertempat di rumah Bapak Yatno Dukuh Ngetuk Desa Ngembalrejo Kecamatan Bae Kabupaten Kudus. Peserta acara tersebut adalah 20 Orang perempuan pengrajin Genteng, 2 orang tim dan seorang narasumber seperti yang sebelumnya yaitu dari PKK. Acara pelatihan yang kedua ini lebih santai, karena ibu-ibu sudah pernah mencoba praktek pada pelatihan menghias baki lamaran yang pertama. Pada hari ini, ibu-ibu mempraktekkan menghias bunga kecil-kecil dari bahan dan beberapa cara bagaimana meletakkan hiasan-hiasan tersebut di dalam keranjang.

Terlihat dari semangat ibu-ibu yang ingin sekali mencoba membuat bunga, burung, daun dan lainnya dengan bahan dasar dari kainbatik maupun bahan untuk mempelai perempuan. Acara berlangsung selama dua jam. Mereka sangat senang sekali, selain mendapatkan ilmu, mereka juga memiliki harapan akan bisa membuka usaha. Pelatihan menghias baki lamaran yang ke dua ini merupakan akhir dari rangkaian acara pelatihan life skill yang sudah dilaksanakan. Oleh karena itu, acara ini dilanjutkan dengan acara penutupan dan serah terima peralatan membuat kue dari Dinas Koperasi Kabupaten Kudus untuk dimanfaatkan oleh ibu-ibu pengrajin genteng yang ada di dukuh Ngetuk Desa Ngembalrejo Kabupaten Kudus. 


\section{ENGAGEMENT}

JurnalPengabdianKepadaMasyarakat

ISSN : 2579-8375 (Print)

ISSN : 2579-8391(Online)
This work is licensed under a Creative Commons

Attribution-ShareAlike 4.0 International License.

\section{c. Pembentukan 'Paguyuban Perempuan Pengrajin Genteng'}

Di awal Desember tepatnya tanggal 9, dua puluh perempuan pengrajin genteng yang telah memiliki ketrampilan membuat kue dan baki lamaran berkumpul kembali membicarakan tentang tindak lanjut pelatihan dan penggunaan peralatan bantuan dari Dinas Koperasi. Dipandu oleh Tim Pendamping, maka disepakati untuk dibentuk organisasi sebagai wadah bersama untuk berusaha bersama. Ada usulan agar dibentuk Kelompok Usaha Bersama (KUB), Koperasi wanita, atau paguyuban perempuan pengrajin genteng. Akhirnya dipilih bentuk yang terakhir, yaitu paguyuban perempuan pengrajin genteng dengan alasan tidak hanya untuk mengelola usaha alternatif bersama, tetapi paguyuban ini sebagai media untuk bersama-sama memperjuangkan peningkatan kualitas hidup mereka sebagai pengrajin genteng yang tidak ingin ditinggalkan. Juga sebagai media untuk berelasi sosial dalam konteks saling tolong menolong, pinjam meminjam uang, dan berbagi pekerjaan. Berbagi pekerjaan kerena mereka tidak ada yang menjadi buruh tetap di satu juragan. Mereka bisa bekerja di mana saja yang sedang berproduksi. Maka paguyuban ini bisa dijadikan sebagai tempat saling berbagi informasi kalau ada pekerjaan.

Di bawah kepemimpinan bu Evi, Di awal Tahun 2017 sampai sekarang, paguyuban ini sudah mulai berjalan dengan diterimanya pesanan kue kering dan basah ketika acara-acara di kampus dan juga di Yayasan Nusantara Satu Kudus maupun acara-acara di masyarakat sekitar. Tampak pula, perempuan pengrajin genteng sudah mulai mengalokasikan sejumlah dana untuk pendidikan bagi anak-anak mereka. Harapanya, anak - anak mereka akan mendapat kehidupan yang lebih baik, yaitu bisa terserap di pabrik-pabrik besar.

Terkait eksistensi paguyuban, beberapa kali paguyuban diundang oleh instansi pemda, diantaranya Badan Pemberdayaan Masyarakat Perempuan dan Keluarga Berencana (BPMPKB) untuk mengikuti pelatihan ketrampilan bagi usaha perempuan. Undangan diwakili oleh anggota paguyuban yang dianggap lebih muda dan berpengalaman.

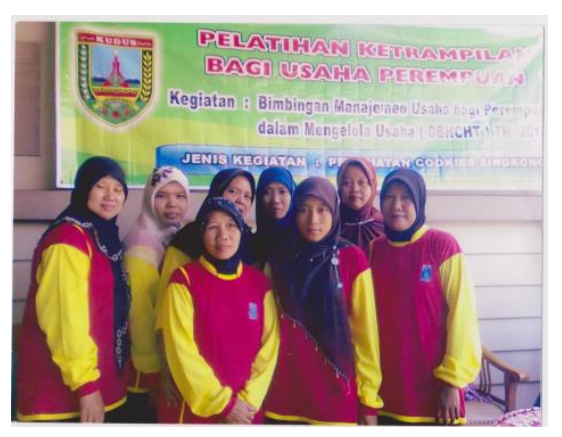

Gambar 18 \& 19

Pelatihan oleh BPMPKB
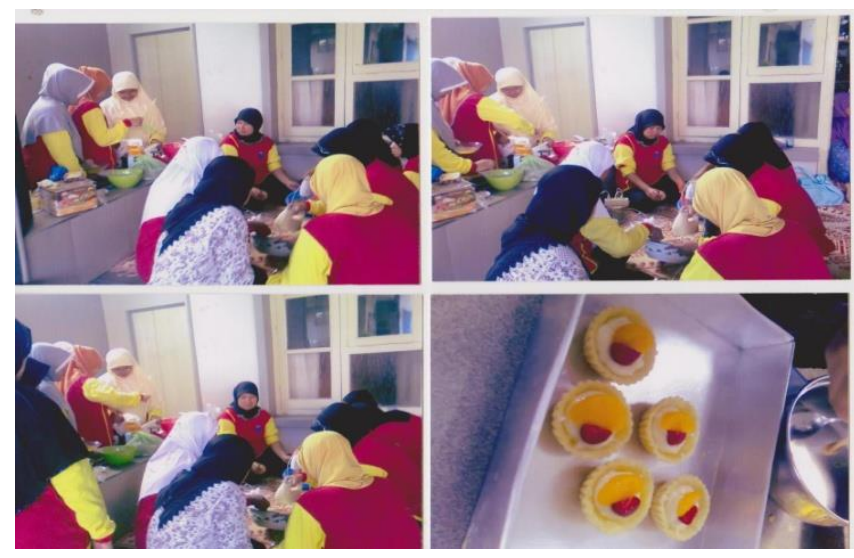


\section{Tahap Evaluasi Kegiatan}

Berdasar hasil wawancara terhadap peserta pelatihan diketahui bahwa mereka sangat puas dan berterima kasih sudah difasilitasi pelatihan-pelatihan yang sangat bermanfaat bagi ketahanan keuangan keluarga mereka. Meski mereka tidak ingin meninggalkan pekerjaan sebagai pengrajin genteng, namun mereka mulai menanamkan kepada anak-anak mereka bahwa pekerjaan yang dijalankan orang tua bukanlah usaha yang prospektif dan terpaksa dijalankan karena tidak ada pilihan lain yang lebih baik. Meski sudah terbentuk paguyuban, namun masih diperlukan penguatan secara kelembagaan atau capacity building bagi pengelola, memperluas jaringan, serta memperluas keanggotaan paguyuban.

\section{Kesimpulan}

Salah satu tanggung jawab perguruan tinggi dan civitas akademika yang ada di dalamnya adalah melakukan pengabdian kepada masyarakat. Tidak perlu jauh-jauh, masyarakat yang dimaksud hendaknya dimulai dari lingkar kampus. Hal ini bukan hanya agar kampus tidak menjadi menara gading bagi masyarakat sekitarnya tetapi sudah menjadi tanggung jawab sosial untuk bersama-sama untuk menghilangkan kedzoliman, ketidakadilan, marjinalisasi, dan eksploitasi. STAIN Kudus yang saat ini sudah menjadi IAIN Kudus sudah berikhtiar melaksanakanya. Dalam rangka mewujudkan kampung lingkar kampus yang bebas dari diskriminasi, eksploitasi dan marjinalisasi diantaranya dengan dilakukanya pendampingan terhadap perempuan pengrajin genteng yang mengalami relasi yang tidak adil di hadapan juragan mereka. Meski sudah berpuluh-puluh tahun bekerja, perempuan pengrajin genteng adalah pihak yang paling sedikit menikmati keuntungan, padahal risiko atas pekerjaan yang dijalankan sangat tinggi antara lain risiko gangguan pernafasan, batuk-batuk, maupun penyakit kulit dikarenakan asap pembakaran. Kondisi ini berbanding terbalik dengan keadaan pemilik usaha genteng yang hampir selalu mengalami peningkatan kesejahteraan. Selain risiko kesehatan yang tinggi, perempuan pengrajin genteng juga tidak memiliki kepastian kerja dan jaminan keselamatan kerja. Tidak adanya kepastian kerja karena mereka hanya dipekerjakan di saat musim kemarau saja, sementara di musim penghujan mereka menganggur. Ketidakpastian juga karena hanya sebagai buruh lepas. Namun, kondisi tersebut tetap dijalani karena bagi mereka tidak ada pilihan pekerjaan lain bagi mereka. Oleh karena itu, pelatihan life skill pembuatan kue kering, kue basah, dan baki lamaran sebagai usaha alternatif diharapkan menjawab ketidakpastian kerja yang selama ini mereka alami. Kegiatan ini diikuti 20 perempuan pengrajin genteng dengan metode praktik langsung. Dilaksanakan selama tiap hari jumat selama bulan September sampai Desember 2016 


\section{ENGAGEMENT}

JurnalPengabdiankepada Masyarakat

ISSN : 2579-8375 (Print)

ISSN : 2579-8391(Online)
This work is licensed under a Creative Commons

Attribution-ShareAlike 4.0 International License.

dan ditutup dengan pelatihan manajemen keuangan keluarga. Hasilnya, perempuan pengrajin genteng memiliki ketrampilan alternatif sehingga tidak ada lagi perempuan yang menganggur di saat musim penghujan tiba. Selain menambah penghasilan juga menambah kepercayaan diri mereka ketika berhadapan dengan juragan dalam penentuan upah dan negosiasi tentang jaminan keselamatan kerja, sebab juragan pun akan terganggu produksinya ketika perempuan-perempuan di sana berhenti bekerja. Selain pelatihan life skill, paguyuban perempuan pengrajin genteng pun berhasil dibentuk sebagai wadah berusaha bersama, berbagi dan saling menguatkan di antara perempuan pengrajin genteng.

\section{Daftar Pustaka}

Anwar. Manajemen Pemberdayaan Perempuan, Bandung: Alfabeta. 2007

Dewayanti, Ratih. dkk. Marjinalisasi dan Eksploitas Perempuan Usaha Mikro di Perdesaan Jawa, Bandung: AKATIGA. 2004

Tajudin. Noor Efendi. Sumber Daya Manusia dan Peluang Kerja dan Kemiskinan. Yogyakarta: Tiara Wacana. 1995

Sutoro, Eko. Pemberdayaan Kaum Marjinal. Yogyakarta: APMD Press. 2005 